\title{
Formulation of Preparing Romantic Room Policy for Prisoners Based on Pancasila Prison System
}

\author{
Desy Maryani ${ }^{1}$, Nur Rochaety ${ }^{2}$ \\ \{desymaryani1985@gmail.com ${ }^{1}$, iyenk283@yahoo.co.id ${ }^{2}$ \} \\ ${ }^{1,2}$ Diponegoro University, Semarang, Indonesia
}

\begin{abstract}
The substance of the Indonesian 1945 constitution has guaranteed the human right of each citizen, even for those in prison, one of those rights is protection. The undergoing of punishment and lose their freedom also deserve to fulfill a psychological need. It includes the right to sexual fulfillment. The absence of sexual desire fulfillment leads to different behaviors. The issues in this paper are: 1) how is the formulation of prisoner right fulfillment recently? 2) How is the formulation of preparing romantic room policy for prisoners based on Pancasila prison system? This research use post-positivism paradigm to guide the writer in analyzing the issue. The approach used in this paper is a socio-legal approach to collect the data from the law as well as social perspective. The results of this discussion are: 1) recently, the policy related to fulfillment of prisoner right is based on national and international law instrument. However, it is still lack of regulation related to fulfillment of sexual needs by preparing the romantic rooms for the prisoners. Instead, there is only legislation related to fulfillment of prisoner right. 2) The formulation of preparing romantic room policy for prisoners based on Pancasila prison system can be done by the explicit formulation of about preparing the romantic room for prisoners in fulfilling their biological needs.
\end{abstract}

Keywords: Formulation Policy, Romantic Room, Pancasila-Based

\section{Introduction}

Pancasila and the 1945 Constitution of the Republic of Indonesia take a prismatic or integrated concept which is between resistant and the rule of law or integrating the principle of legal certainty and the principle of fairness(1). As a state law of Pancasila, the state must provide a guarantee of proper protection, treatment, and law enforcement for all citizens, including prisoners.

Correctional Institution as a part of the criminal justice system, i.e., as a coaching institution, has a very strategic role in realizing the ultimate goals of the criminal justice system, namely, rehabilitation and resocialization of offenders. Correctional strategy as a process does not stand alone. Instead, it is the result of a series of the law enforcement process. Therefore, it can be said that the correctional institution is a sub-system of the criminal justice system(2). Integrated punishment is the effort of coaching and returning the prisoners into an excellent and useful society. However, in reality, there is a gap between das sollen and das sein of the correctional goal.

The occurrence of sexual harassment, as well as clandestinely sexual behaviors, with or without the cooperation of the officer, is a realization of sexual fulfillment among the prisoners. Cases of sexual harassment behavior occur in many prisons, such as anal sex that occurs due to the blockage of sexual fulfillment from prisoners. It is typical for homosexual 
cases in prison; it is not a new issue anymore(3). As a result, every time, there are always prisoners who become victims of sexual harassment. This representation shows a problem faced by the Correctional System in Indonesia.

Law enforcement, according to NyomanSerikat Putra Jaya, is not only interpreted as the application of positive law but also the creation of positive law(4). The creation of positive law which is the meaning of law enforcement indicates that a law reform based on iusconstitutumto iusconstituendum. This means that the solution in providing the rights of the prisoners especially about the fulfillment of the sexual needs is by making a formulation policy for the provision of spaces for the prisoners to overcome the harassments that occur in a correctional institution.

\section{Methodology}

The method approach used in this study is socio-legal. The socio-legal study is a study of law by using the approach of law science and social sciences(5). The socio-legal approach is used in this study in order to get data, both from the aspect of law science and social sciences (interdisciplinary nature). Therefore, a more in-depth and meaningful analysis of the articles in the legislation can be carried out.

\section{Findings}

\subsection{The current policy of prisoner right fulfillment formulation in correctional institutions}

\subsubsection{International Convention related to the rights of prisoners}

a) Article 5, Article 12 of the Universal Declaration of Human Rights

b) Article 12 (1) of the International Covenant on Economic, Social and Cultural Rights

c) Article 10, Article 17, in the International Covenant on Civil and Political Rights

3.1.2. National instruments related to the rights of prisoners as citizens and prisoners. Several rules on the rights of prisoners are as follows:

1) The rights of prisoners as citizens

a) Article $28 \mathrm{~B}$, Article $28 \mathrm{H}$, Article 15 of the 1945 Constitution of the Republic of Indonesia

b) Article 4, Article 6, Article 15, Article 18, Article 72, Article 73 in the Law No. $36 / 2009$ on Health

2) The rights of prisoners as prisoners

a) In consideration of the Law, Article 1 point (2), Article 5, Article 14 paragraph (1) of the Law No. 12/1995 on Correctional Institution.

b) Article 30 of the Regulation of Government of the Republic of Indonesia No. 32/1999 on Terms and Procedures for the Implementation of Prisoner Rights.

c) Article 34, Article 36, Article 41, Article 43 government Regulation No. 28/2006 on Amendment to Government Regulation Number 32/1999 on Terms and Procedures for the Implementation of Prisoner Rights in the Correctional Institution.

d) Article 34, Article 34 A, Article 36, Article 43 of the Government Regulation No. 99/2012 on the Second Amendment to Government Regulation No. 32/1999 on 
Terms and Procedures for Implementation of Prisoner Rights in the Correctional Institution.

Based on the terms of the Articles above, they merely regulate remission, assimilation, leave, free leave, and parole, instead of regulating the right of prisoners in the fulfillment of sexual needs. The provisions of the articles above indicate the lack of instruction or legislation which regulates in detail the fulfillment of sexual needs for prisoners. Therefore, the officers of Correctional Institution cannot perform the fulfillment of sexual needs for the prisoners.

The fulfillment of the sexual needs of prisoners has not been paid special attention; thus, it needs a policy that takes into account the sexual rights of the prisoners. The policy of criminal law enforcement is a series of processes consisting of three stages of policy, namely(6) :

1) Formative or legislative policy stage is the formulation stage of criminal law

2) Judicial or applicative policy stage is the application stage of criminal law

3) Executive or administrative policy stage is the execution stage of criminal law

If it is seen from the point of crime prevention policy planning and penal policy, the formative or legislative policy stage is the most strategic. Any mistake or weakness in legislative policy is the strategic mistake that can be an obstacle for crime prevention and control at the applicative and executive stages(7).

The legislation or formulation process is a very strategic preliminary planning stage of the law enforcement processes. Ruslan Saleh states that law is part of a specific policy; it is not only a tool to implement the policy, but also determines, outlines, or designs the policy(8). Therefore, the mistake or weaknesses at the legislative or formative policy stage is a strategic mistake that can be the obstacle to law enforcement efforts in concreto.

Formative policy stage is the basis, direction, substance, and limit of authority in law enforcement that will be carried out by the bearers of judicial and executive authorities; thus, the formative stage brings the consequence that the weakness of criminal law formulation policy will affect the criminal law enforcement policy. It is expected to realize the purpose of punishment that is mostly regarded not as an act of retaliation from the state(9). The guidance of these prisoners is put in the framework of assurance in which everybody is treated as a human being.

In the process of punishment, prisoners are only sentenced to the loss of independence; thus, the prisoners are entitled to receive their rights as prisoners, including the right to fulfill their sexual needs. There have been several studies that have reviewed the issue of the biological needs of the prisoners, e.g., Center for Studies and Development at the Ministry of Justice and Human Rights reported the defects experienced by prisoners when their biological needs are not channeled. Also, in the aspect of sexual behavior, it describes their sexual deviation (sexual harassment) as well as sexual behaviors clandestinely, with or without the cooperation of the officers, as a form of sexual fulfillment(3). Based on the impact of the nonfulfillment of the sexual rights of the prisoners, the romantic rooms are needed to assist the prisoners in being able to channel their sexual needs. It is because the fulfillment of sexual needs affects the behavior of the prisoners, especially for those who have got married. Therefore, the provision of romantic rooms for the prisoners is essential to have the development processes run well.

\subsection{Policies of romantic romance provision formulation as an effort to fulfill the rights of prisoners in Correctional Institution based on Pancasila}

1. The need for the provision of romantic space as an effort to fulfill the sexual needs of prisoners in the Correctional Institution

a) Current conditions of the prisoner right fulfillment in a correctional institution 
Based on the interviews with some prisoners, they had sexual intercourse with animals, had sexual intercourse with transgender people, and suppressed new prisoners for oral sex; as a result, they got sexual deviation(10). The most apparent fulfillment of the sexual needs of prisoners is shown through the current conditions. The Correctional Institution has provided a romantic room for the prisoners; however, there has been no explicit policy regarding the provision of a romantic room. As a result, there are many irregularities in the distribution of sexual needs for the prisoners.

b) The fulfillment of sexual needs for prisoners in Correctional Institution from the perspective of human rights.

Human rights mostly contain two faces, namely human rights in the sense of "Human Rights" and human rights in the sense of "Human Rights of Society." These two aspects are the characteristics and the legal identity of the humanitarian aspect and social aspect(11). It suggests that it is evident in the recognition and interconnection between the humanitarian aspect and social aspect. Likewise, the government policy in the provision of a romantic room for the prisoners in Correctional Institution for the fulfillment of sexual needs reflects the humanitarian and social aspects.

\section{The establishment of correctional penal system based on Pancasila}

Pancasila as the basis of Indonesian philosophy itself is a unity. Each pillar is essentially an element of Pancasila. The five pillars are necessarily a unity that derives from the nature of the Pancasila pillars(12). Likewise, the provision of the romantic room is the embodiment of individual needs fulfillment (in this case, the prisoners), because based on fair and civilized humanity.

3. Based on comparative law on the provision of a romantic room in other countries

Comparative law can be used to describe a systematic study of legal traditions and specific comparative-based legal rules(13). This section will describe the provision of a romantic room in fulfilling the sexual needs of prisoners in various countries, including Brazil, the United States, Israel, and Malaysia.

4. The policy of romantic room provision formulation for the prisoners aiming at Pancasilabased correctional system

The formulation policy stage or the legislative policy stage is an effort to compose or make a policy(6), as well as the provision of a romantic room in Correctional Institution. Assessing the existing rules, the correctional system in Indonesia is an order of direction, boundary, and way of guidance of prisoners based on Pancasila which is implemented in an integrated manner between the mentors, prisoners, and the community.

Based on the information elaborated above, the mechanism idea of fulfilling the biological needs of prisoners is formulated in a policy as follows:

a) The state needs to set the biological needs explicitly as prisoners' rights in legislation, with the formula: "every Correctional Institution shall provide facilities of Conjugal Visit by providing romantic room for at least ten special room to receive visitors."

b) The procedures of Conjugal visit (family visits), with the formula: "Before entering the romantic room, some requirements must be fulfilled by visitors, such as the visitors must bring a marriage certificate, family card, and ID card."

c) The duration of conjugal visits for the fulfillment of the right to the biological needs of 
prisoners should also be explicitly considered, with the formula: "every prisoner who uses the romantic is given time for 1 x 60 minutes."

\section{Conclusion}

Referred to the discussion above, it can be concluded as follows:

a. The policy of prisoner right fulfillment formulation in Correctional Institution is currently regulated in international instruments and national instruments

b. The policy of romantic romance provision formulation as an effort to fulfill the rights of prisoners in Correctional Institution based on Pancasila are:

1) The State needs to explicitly regulate biological needs as the right of prisoners in the law,

2) The procedures of Conjugal visit

3) The duration of conjugal visits for the fulfillment of the right to the biological needs of prisoners should also be explicitly considered

\section{References}

[1] MD. M. Mahfud. Membangun Politik Hukum Menegakkan Konstitusi. Jakarta: Rajawali Press; 2012.

[2] N. Rochaeti, "Pembinaan Narapidana di Lembaga Pemasyarakatan Kedung Pane," Semarang. J Masal Huk. 2004

[3] L. Susanti, Pola Adaptasi Narapidana Laki-Laki dalam Pemenuhan Kebutuhan Seksual di Lembaga Pemasyarakatan Klas I Cipinang [Internet]. Universitas Indonesia; 2009. Available from: http://lib.ui.ac.id/file?file=digital/128696-T 26716Pola adaptasi-HA.pdf

[4] N. S. P. Jaya, Tindak Pidana Korupsi, Kolusi, dan Nepotisme di Indonesia. Semarang: Badan Penerbit UNDIP; 2008

[5] I. Sulistyowati, Shidarta. Metodologi Penelitian Hukum, Konstelasi dan Refleksi. Jakarta: Yayasan Obor Indonesia; 2013

[6] B. N. Arief, Kebijakan Formulasi Ketentuan Pidana Dalam Peraturan Perundangundangan. Semarang: Pustaka Magister; 2015.

[7] B. N. Arief, Pornografi, Pornoaksi, cybersex dan cyberporn. Semarang: Pustaka Magister; 2011

[8] R. Saleh, Segi Lain Hukum Pidana. Jakarta: Ghalia Indonesia; 1984

[9] Hermidi B. "Pembinaan Narapidana Sebagai Upaya Untuk Mewujudkan Tujuan Pemidanaan." J Masal Huk. Vol. 31 (1), p. 15. 2002.

[10] A. Taufik, Bisnis Sex di Balik Jeruji. Jakarta: Ufuk Press; 2010

[11] B. N. Arief, Bunga Rampai Kebijakan Hukum Pidana, Perkembangan Penyusunan Konsep KUHP Baru. Jakarta: Kencana; 2008.

[12] Kaelan. Filsafat Pancasila, Pandangan Hidup Bangsa Indonesia. Yogyakarta: Paradigma; 2009.

[13] Cruz P de. Perbandingan Sistem Hukum Common Law, Civil Law and Socialist Law. Bandung: Nusa Media; 2016. 